\title{
Measurement of Gestagen Concentration in Feces Using a Bovine Milk Progesterone Quantitative Test EIA Kit and Its Application to Early Pregnancy Diagnosis in the Sow
}

\author{
Masaharu MORIYOSHI, Kouya NOZOKI, Tadatoshi OHTAKI, Ken NAKADA, Toshihiko NAKAO, \\ and Keiichiro KAWATA \\ Department of Veterinary Obstetrics and Gynecology, Faculty of Veterinary Medicine, Rakuno Gakuen University, Ebetsu, Hokkaido \\ 069, Japan
}

(Received 27 August 1996 /Accepted 14 April 1997) \begin{tabular}{l} 
ABSTRACT. We attempted to measure the gestagen concentration in the feces of pigs by using a commercial bovine milk progesterone \\
quantitative test EIA kit, and investigated the possibility of applying of this method of gestagen concentration measurement to early \\
pregnancy diagnosis in the sow. Feces were collected from the rectum of the pig, and $0.5 \mathrm{~g}$ of the feces was placed in $20 \mathrm{~m} l$ of distilled \\
water, stirred, and centrifuged. The supernatant was used as the fecal solution for measurement of gestagen. The procedure used for \\
measuring gestagen in feces was the same as that for the measurement of progesterone in milk, except that a standard fecal gestagen \\
solution $(0.5-30.0 \mathrm{ng} / \mathrm{m} l)$ was prepared by the authors in the laboratory. The sensitivity of measurement using this method was $0.80 \mathrm{ng} /$ \\
$\mathrm{m} l$, or $32.0 \mathrm{ng} / \mathrm{g}$ of fecal weight. The recovery was $105.2-105.6 \%$. Intra-assay coeffecients of variation $(\mathrm{CVs})$ were $2.8-8.5 \%$. The inter- \\
assay CVs were $7.4-10.2 \%$. Gestagen concentrations in feces measured by the present method and progesterone concentrations in \\
peripheral plasma, collected at the same time as the feces, were highly correlated ( $\mathrm{r}=0.98$, p $<0.001)$. The criteria for diagnosis of \\
pregnancy based on the fecal gestagen level was positive for a gestagen level of $\geqq 200 \mathrm{ng} / \mathrm{g}$ and negative for a gestagen level of $<200 \mathrm{ng} /$ \\
$\mathrm{g}$. When fecal gestagen measurements were applied to early pregnancy diagnosis in 149 sows, the accuracy of diagnosis from day 21 to \\
day 25 after the last mating was $96.2 \%$ for positive cases (102/106) and $95.3 \%$ for negative cases (41/43). Thus, the results of this study \\
show the quantitative measurement of the fecal gestagen concentration in the sow using a bovine milk quantitative test EIA kit is a \\
practical method for early pregnancy diagnosis. - KEY wORDs: early pregnancy diagnosis, feces, gestagen, quantitative test EIA kit, sow. \\
\hline
\end{tabular}

Blood samples have generally been used to measure the sex steroid hormone concentration in animals for the purpose of assessing the ovarian function. Milk [11, 12, 32, 33], saliva $[11,18,35,42]$, urine $[4,21,24]$ and feces $[6,13$, $20,31,34,40,49]$ are easier to collect than blood. These have been used as measurement samples to measure the steroid hormone concentration in animals, and good results have been reported in many cases. The measurement of the steroid hormone concentration in feces has been reported to be a useful method for wild animals and pigs, from which blood collection is especially difficult $[2,4,14,22,25,37$, 39]. However, most of these reports on the use of fecal samples used radioimmunoassay (RIA) for the measurements, and as RIA can only be performed at a very limited number of laboratories due to various restrictions, and requires a long time for measurement, these reported methods of measurement using fecal samples have low applicability to the clinical field of veterinary medicine.

For efficient breeding of livestock, it is important to diagnose a pregnancy as soon as possible after mating and then to treat the non-pregnant animals appropriately in order to minimize the non-pregnant period. This requires a reliable method of early pregnancy diagnosis. Various methods of early pregnancy diagnosis for sows have been reported $[1,3,7-10,15,16,19,23,24,30,36,38,43$, 46, 48]. However, all of these methods have problems in terms of simplicity, cost, and accuracy, and have not come to be used widely in the clinical field.

In a previous study [27-29], the authors measured the progesterone concentration in the saliva of sows, which is easier to collect than blood. Measurements were carried out using a commercial bovine milk progesterone enzyme immunoassay (EIA) kit, which is quick and does not require any special equipment. The authors reported good results from the application of this method to early pregnancy diagnosis in sows [27-29]. In the present study, the same commercial bovine milk progesterone EIA kit was used for quantitative measurement of the gestagen concentration in samples of feces, which are even easier to collect than saliva, and the applicability of this method to early pregnancy diagnosis in the sow was investigated.

\section{MATERIALS AND METHODS}

Test kit: The kit used for gestagen quantitative measurement was an Ovucheck bovine milk progesterone EIA kit (Cambridge Veterinary Sciences Ltd., U.K.). The microtitre plate had 96 wells with sheep progesterone antibody pre-coated in each well. The reagents included enzyme-labeled antigen-binding solution (conjugate), substrate tablets, substrate tablet soluble buffer solution, and stopping solution, as well as four types of standard progesterone milk solutions $(1.0,5.0,10.0,30.0 \mathrm{ng} / \mathrm{ml}$; standard milk solution was not used in the present experiments). As we did not investigate the cross reaction between the sheep progesterone antibody used in the kit and progesterone metabolites (conjugated progesterone) included in feces, the substances measured by this kit were expressed as gestagen (progesterone and progesterone metabolites).

Standard fecal gestagen solution preparation: Fecal 
samples were collected from 5 sows in estrus by a method described later. The fecal solutions produced were pooled and treated by dextran-coated charcoal [26], and steroids in the fecal solution were removed. This was added to a standard progesterone methanol solution, which had been previously poured into a test tube and dried at $85^{\circ} \mathrm{C}$, and the standard fecal gestagen solutions were made by adjusting the solutions to final progesterone concentrations of 0.5 , $1.0,5.0,10.0$ and $30.0 \mathrm{ng} / \mathrm{ml}$.

Measurement procedure: Measurements were carried out according to the procedure for the kit outlined in Fig. 1, except that test fecal solution and standard fecal solution were used instead of milk. The time required for measurement was less than $1.5 \mathrm{hr}$. Values were calculated as the concentration (content) of gestagen per $1 \mathrm{~g}$ of feces.

Fecal collection and fecal solution preparation: Fecal collection was carried out while the sow remained unrestrained in its stall. A plastic glove for rectal examination was worn on the hand which was inserted into the rectum of the sow. An appropriate amount of impacted feces was taken from the rectum and immediately weighed into $0.5 \mathrm{~g}$ amounts, which was put into a plastic test tube containing $20 \mathrm{~m} l$ of distilled water with $0.05 \%$ of sodium azide as an antiseptic added, and then taken back to the laboratory. After stirring well, the solution was centrifuged at $1,700 \times \mathrm{g}$ for $15 \mathrm{~min}$, and the supernatant was frozen at $-20^{\circ} \mathrm{C}$, as the fecal solution, until the gestagen measurement.

Blood collection and plasma preparation: Immediately after fecal collection, blood was also collected from the same sow for a comparison with progesterone in the blood. A 21 gauge $(5 / 8$ inch) needle was inserted into the median vein of the tail, while the sow remained unrestrained in its stall, and blood was collected in a small test tube containing heparin. The blood was centrifuged $(1,700 \times \mathrm{g}, 15 \mathrm{~min})$ and the plasma was also frozen at $-20^{\circ} \mathrm{C}$ until progesterone measurement using commercial Ovucheck blood plasma/ serum progesterone EIA kit (Cambridge Veterinary Sciences Ltd., U.K.) [29, 44].

Reliability of measurements: The sensitivity of gestagen and reproducibility of measurements in fecal solution using the kit were analyzed, and the correlation between the gestagen measurement and progesterone measurements in fecal solution by double antibody EIA was also investigated. In the double antibody EIA [17] progesterone was measured after extraction as follows: $2 \mathrm{~m} l$ of petroleum ether was added to $0.05 \mathrm{ml}$ of test fecal solution, and after stirring for approximately $30 \mathrm{sec}$ the ether layer was removed and evaporated to dryness at approximately $55^{\circ} \mathrm{C}$. After adding $0.1 \mathrm{~m} l$ of $0.1 \mathrm{M}$ phosphate-buffer solution to the dried test fecal sample and gently mixing, double antibody EIA was performed. The correlation between gestagen in feces, measured by the Ovucheck bovine milk progesterone EIA kit, and progesterone in plasma, measured by the Ovucheck blood plasma/serum progesterone EIA kit, was also investigated.

Animals subjected to examination: Changes in the fecal

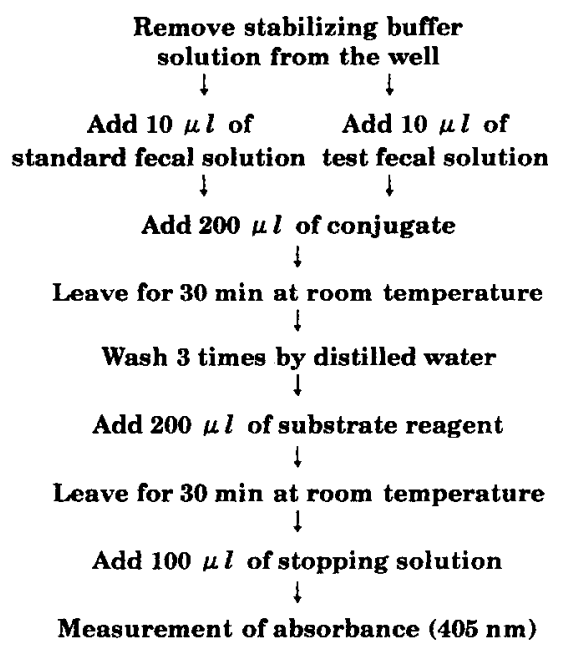

Fig. 1. Outline of the procedure for quantitative measurement of fecal gestagen in the sow using a Ovucheck bovine milk progesterone EIA kit.

gestagen concentration during the estrous cycle; Feces and blood were collected by the previously described method, from five hybrid sows raised in the authors' laboratory, at two-day intervals over one complete estrous cycle starting from the first day of estrus (day 0) until the final day of the next estrus.

Animals subjected to examination: Early pregnancy diagnosis; A total of 149 sows, including 21 Large White sows, 2 Landrace sows and 126 Large White and Landrace first-generation crossbred sows, at day 21 to day 25 after their last mating (day 0), were selected for the experiments from breeding sows raised at a swinery near our university. These sows had been raised in individual stalls, measuring $60 \mathrm{~cm}$ in width $\times 180 \mathrm{~cm}$ in length $\times 103 \mathrm{~cm}$ in height. The floor of each stall was concrete, and was maintained in a continuously dry state by a covering of sawdust. The feed was commercially available compound feed for breeding sows (High Breed $80^{\mathrm{R}}$, Hokuren, Japan), and was fed to the sows by an automatic feeding device 3 times a day at a rate of 2.1-3.0 kg per sow. Water was freely available at all times. Generally, the quality of feces excreted by such sows is nonviscous lumps with a low water content, and there were almost no differences in the feces quality between sows in this study.

The criteria for diagnosis of pregnancy based on the fecal gestagen level was positive for $\geqq 200 \mathrm{ng} / \mathrm{g}$ and negative for $<200 \mathrm{ng} / \mathrm{g}$. Clarification of pregnancy was made by ultrasonography after day 22 of the last mating $[15,16]$.

\section{RESULTS}

Standard curve: An example of the standard curve for gestagen in feces obtained by the Ovucheck bovine milk progesteone EIA kit is shown in Fig. 2. As there is no $0 \mathrm{ng} /$ $\mathrm{m} l$ of standard gestagen, the sensitivity of measurement (the least detectable amount) was estimated from the standard 


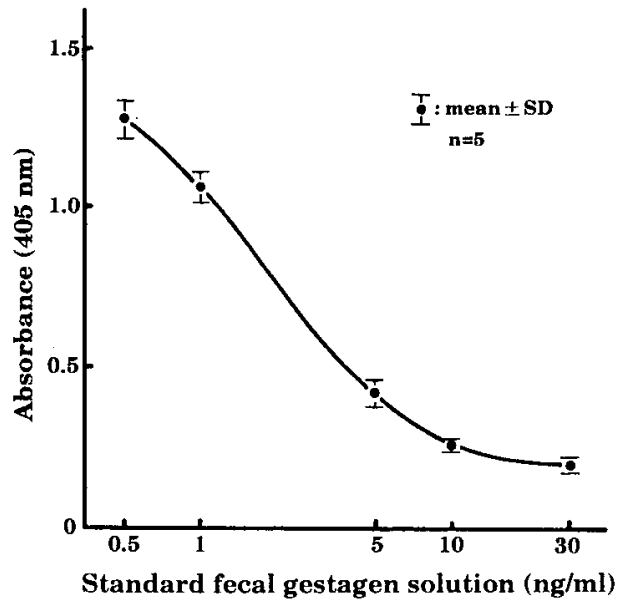

Fig. 2. Standard curve for Ovucheck bovine milk progesterone EIA kit of gestagen in swine fecal solution.

curve as the gestagen concentration, which corresponded to the value of two times standard deviation away from the mean absorbance $(\mathrm{n}=5)$ at $0.5 \mathrm{ng} / \mathrm{ml}$ of standard gestagen. The sensitivity was $0.80 \mathrm{ng} / \mathrm{ml}$ of fecal solution, or $32.0 \mathrm{ng} /$ $\mathrm{g}$ of fecal weight.

Recovery: The average recovery rate of predetermined amounts of progesterone $(1.0,5.0,10.0,20.0 \mathrm{ng})$ added to two $1 \mathrm{~m} l$ pooled fecal solutions containing different concentrations of gestagen were $105.2 \%$ in the fecal solution with low gestagen concentration and $105.6 \%$ in the one with high gestagen concentration.

Precision: The intra-assay coefficient of variation, obtained by five replicate assays in two pooled fecal solutions containing different concentrations of gestagen, was $8.5 \%$ (mean $4.7 n \mathrm{~g} / \mathrm{ml}$, or $188 \mathrm{ng} / \mathrm{g}$ of fecal weight) in the fecal solution with low gestagen concentration and $2.8 \%$ (mean $24.6 \mathrm{ng} / \mathrm{ml}$, or $984 \mathrm{ng} / \mathrm{g}$ of fecal weight) in the one with high gestagen concentration. The inter-assay coefficient of variation obtained by a further five replicate assays was $10.2 \%$ (mean $4.9 \mathrm{ng} / \mathrm{ml}$, or $196 \mathrm{ng} / \mathrm{g}$ of fecal weight) in the fecal solution with low gestagen concentration and $7.4 \%$ (mean $24.3 \mathrm{ng} / \mathrm{ml}$, or $972 \mathrm{ng} / \mathrm{g}$ of fecal weight) in the one with high gestagen concentration.

Comparison of measurements of gestagen in feces by the Ovucheck EIA kit and measurements of progesterone in feces by the double antibody EIA: The correlation coefficient and regression equation between measurements of gestagen in feces by the Ovucheck bovine milk progesterone EIA kit and measurements of progesterone in feces by the double antibody EIA were $r=0.95(\mathrm{p}<0.001)$ and $\mathrm{y}=3.29 \mathrm{x}+29.24$ $(\mathrm{n}=8)$.

Comparison of measurements of gestagen in feces and measurements of progesterone in plasma: The correlation coefficient and regression equation between measurements of gestagen in feces by the Ovucheck bovine milk progesterone EIA kit and measurements of progesterone in plasma were $\mathrm{r}=0.98(\mathrm{p}<0.001)$ and $\mathrm{y}=18.58 \mathrm{x}-2.18(\mathrm{n}=8)$.

Fecal gestagen levels during the estrous cycle: Changes in the fecal gestagen level by Ovucheck bovine milk progesterone EIA kit and plasma progesterone level by Ovucheck blood plasma/serum progesterone EIA kit during the estrous cycle are shown in Fig. 3. The changes in the fecal gestagen level were almost the same as those of plasma progesterone, except that there was a two-day delay in the fecal gestagen level changes compared to the plasma progesterone level changes. Also, the average level of fecal gestagen during the estrus and early luteal phase(day 0-4), and the functional luteal phase (day 8-18) of the estrous cycle was $71 \pm 25 \mathrm{ng} / \mathrm{g}($ mean $\pm \mathrm{SD})$ and $497 \pm 118 \mathrm{ng} / \mathrm{g}$, respectively.

Results of early pregnancy diagnosis: Figure 4 shows the distribution of gestagen concentrations in feces from day 21

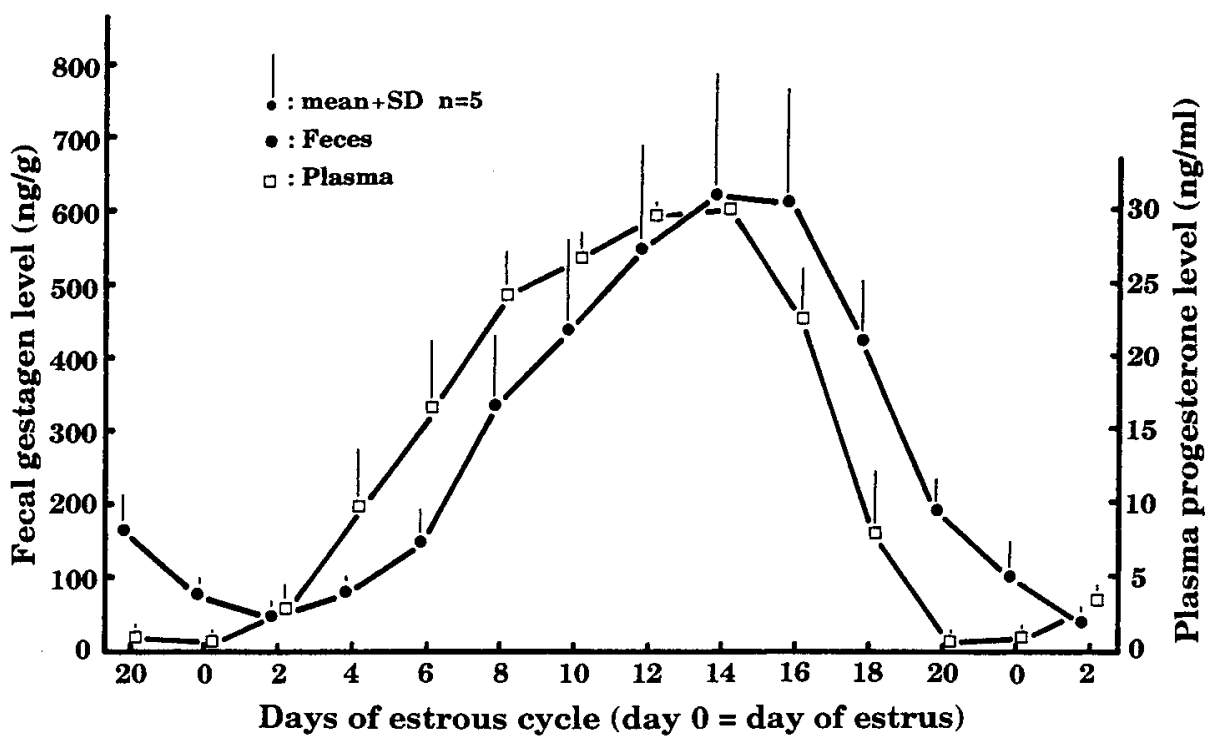

Fig. 3. Concentrations of gestagen in feces ( $)$ and progesterone in plasma ( $\square$ ) during estrous cycle in five sows. 


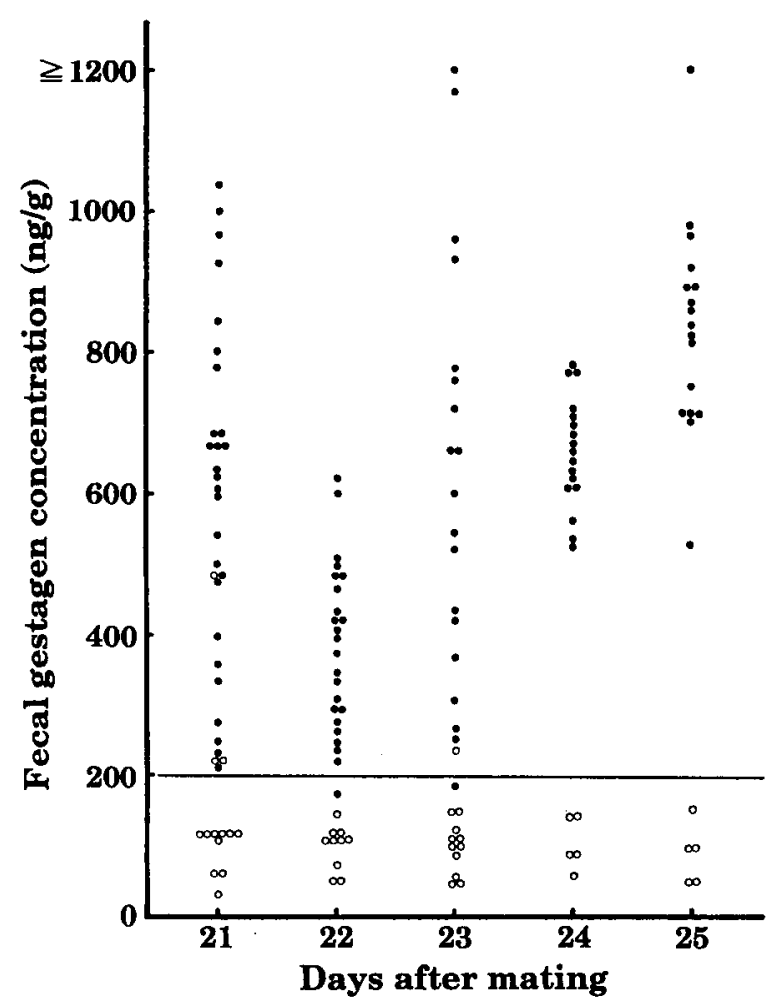

Fig. 4. Fecal concentrations of gestagen in 149 sows on days 21 to 25 after mating (day $0=$ day of last mating). pregnant, $\bigcirc$ non-pregnant.

to day 25 of the last mating. A comparison of the early pregnancy diagnosis with the fecal gestagen concentration, based on the criteria of positive for a gestagen level of $\geqq$ $200 \mathrm{ng} / \mathrm{g}$ and negative for $<200 \mathrm{ng} / \mathrm{g}$, and the ultrasonography, performed after day 22 of the last mating, showed that, except for 3 cases on day 21,1 case on day 22 and 2 cases on day 23, the early pregnancy diagnoses agreed with the diagnoses by ultrasonography in all other cases.

The accuracies of the pregnancy diagnosis by measurement of the fecal gestagen concentration from day 21 to day 25 of the last mating are shown in Table 1 . The accuracy of negative pregnancy diagnosis based on the fecal gestagen level was $100 \%$ on day $21,90.9 \%$ on day 22 ,
$91.7 \%$ on day $23,100 \%$ on day 24 , and $100 \%$ on day 25 after the last mating. The accuracy of positive pregnancy diagnosis was $90.0 \%$ on day $21,100 \%$ on day $22,94.7 \%$ on day $23,100 \%$ on day 24 , and $100 \%$ on day 25 . As for the overall accuracy of pregnancy diagnosis, 102 of 106 cases (96.2\%) diagnosed as positive pregnancy by the fecal gestagen level were verified as positive pregnancy by ultrasonography, and 41 of 43 cases $(95.3 \%)$ diagnosed as negative pregnancy by the fecal gestagen level were verified as negative pregnancy by ultrasonography. The overall accuracy of both positive and negative pregnancy diagnosis by the fecal gestagen level was $96.0 \%$.

\section{DISCUSSION}

In the case of pigs, blood is generally collected from the cranial vena cava or caudalauricular vein by retention of the nose. Retention of the pig involves great effort and the risk of accidents, and is also thought to be very stressful for the pig. Thus, in the present study, the authors investigated the reliability of measuring the gestagen concentration in feces, which is easier to collect than blood, by a bovine milk progesterone EIA kit. The measurement procedure is exactly the same as that using milk. However, as this is a direct EIA kit and the fecal solution is poured directly into the wells, standard fecal solutions were prepared and used. The measurement sensitivity of gestagen, estimated from the standard curve, was $0.80 \mathrm{ng} / \mathrm{m} l$ of fecal solution, or 32.0 $n \mathrm{~g} / \mathrm{g}$ of fecal weight, which is almost the same as previously reported results for the Ovucheck progesterone EIA kit [28, $44,45,47]$, and indicates it is a sufficiently practicable method. The reproducibility of measured values is also similar to that of previous reports [28, 44, 45, 47], and is not inferior to other methods of measurement. The recovery rate was $105.2-105.6 \%$, which was quite satisfactory. A comparison of gestagen measurements using the Ovucheck bovine milk progesterone EIA kit and progesterone measurements using the double antibody method for the same fecal sample of a pig showed that the two were highly correlated, although the measurements using the Ovucheck bovine milk progesterone EIA kit were very high. The reason for this, as Hultén et al. [14] also pointed out, is thought to be because the gestagen level measured by the

Table 1. Accuracy of pig pregnancy diagnosis on days 21 to 25 after mating by EIA kit of fecal gestagen

\begin{tabular}{lrrrrrr}
\hline & \multicolumn{7}{c}{ Day after mating (day 0 day of last mating) } & \multirow{2}{*}{ Total } \\
\cline { 2 - 5 } & 21 & 22 & 23 & 24 & 25 & \\
\hline No. of sows examined & 40 & 34 & 31 & 22 & 22 & 149 \\
Diagnosed pregnant by EIA ${ }^{\text {a) }}$ & 30 & 23 & 19 & 17 & 17 & 106 \\
Diagnosed pregnant by US & 27 & 23 & 18 & 17 & 17 & 102 \\
Accuracy (\%) of positive pregnancy by EIA & 90.0 & 100 & 94.7 & 100 & 100 & 96.2 \\
Diagnosed non-pregnant by EIA & 10 & 11 & 12 & 5 & 5 & 43 \\
Diagnosed non-pregnant by US & 10 & 10 & 11 & 5 & 5 & 41 \\
Accuracy (\%) of negative pregnancy by EIA & 100 & 90.9 & 91.7 & 100 & 100 & 95.3 \\
Total \% & 92.5 & 97.1 & 92.3 & 100 & 100 & 96.0 \\
\hline
\end{tabular}

a) Fecal gestagen measurement by Ovucheck EIA kit.

b) Real-time ultrasonic scanning method. 
Ovucheck bovine milk progesterone EIA kit not only includes progesterone but also a considerable amount of progesterone metabolites in the feces. A high correlation was also seen between the fecal gestagen concentration and plasma progesterone concentration in pigs measured by the Ovucheck progesterone EIA kit. The results of this study have shown that measurement of the gestagen concentration in the feces of pigs by the Ovucheck bovine milk progesterone EIA kit satisfies criteria for reliability and practicability, and in addition, is an efficient method, requiring only $1.5 \mathrm{hr}$ to perform.

Hultén et al. [14] compared the changes in fecal gestagen and blood serum progesterone concentrations in the pig during the estrous cycle, and reported that the changes in the fecal concentration were similar to those in the blood serum concentration, but with an approximately two-day delay. We obtained very similar results in the present study. Our results also agree with those by Hirata and Mori [13], who compared progesterone levels in feces and blood serum of the goat during the estrous cycle. The results also accord with those of Choi et al. [4], who monitored the changes in the estrogen level in the sow during the first trimester of pregnancy, and reported that the changes in the estrogen level in feces were similar, but with a two-day delay, to those of the estrogen level in blood serum. The steroid hormones included in the feces come from the blood steroid hormones, which have been metabolized by the liver and released into the digestive tract as metabolites, or have been transferred directly from peripheral blood in the alimentary blood vessels of the digestive tract into peptic juice or mucus (secreting fluid). These hormones are contained in decomposed food in the digestive tract, and are thought to take approximately two days to be finally excreted from the body in the feces. This point must be considered in the clinical application of fecal gestagen concentration measurement.

To the best of our knowledge, there has been no other report on early pregnancy diagnosis in the pig using measurements of the gestagen level in feces. First, it was necessary to establish the period for carrying out pregnancy diagnosis using this method. The authors, as well as Hultén et al. [14], confirmed that the pattern of changes in fecal gestagen were the same, except for a two-day delay, as that of plasma progesterone. Early pregnancy diagnosis using measurements of plasma progesterone is carried out from day 19 to day 23 after last mating, therefore the period for early pregnancy diagnosis using measurements of fecal gestagen in the present study was set two days after this, i.e. from day 21 to day 25 after last mating. The level of 200 $n \mathrm{~g} / \mathrm{g}$ of gestagen in feces was established as the borderline for determination of pregnancy or non-pregnancy in the sow, based on the results of this study which showed that the level of fecal gestagen during the estrus and early luteal phase (day 0-4), and the functional luteal phase (day 8-18) of the estrous cycle was $71 \pm 25 \mathrm{ng} / \mathrm{g}$ and $497 \pm 118 \mathrm{ng} / \mathrm{g}$, respectively.

Measurements of the steroid hormone level in feces have often been carried out after first drying the feces and then performing extraction using an organic solvent, which is a complex procedure [13, 41]. However, Hultén et al. [14] measured the gestagen level in the feces of pigs by the following simple procedure: after freezing the collected feces, the feces were added to a $0.01 \mathrm{M}$ phosphate-buffer solution and stirred immediately before measurement, and the supernatant was subjected to measurement by RIA. The method of measurement used in the present study is an even more simplified method than that of Hultén et al. [14]: after collection, the feces were immediately placed in distilled water, mixed, centrifuged and the supernatant was used for measurement. Moreover, for the measurement of gestagen in the present study, we used a commercially available Ovucheck bovine milk progesterone EIA kit, which is quick and does not require any special equipment for measurement, compared to RIA which is subject to various restrictions. This method of gestagen measurement can be performed in most clinics and laboratories, and is considered to have a high clinical applicability for pregnancy diagnosis in the sow.

The reported accuracies of other main methods of pregnancy diagnosis for the sow are: $81.3-85.2 \%$ for the rectal examination method at 20 days after mating [1, 3, 10, 19], 94.0-97.0\% for the vaginal mucosal tissue examination at 20 days after mating [7, 30], 58.0-80.0\% at 22 days after mating and $91.9-100 \%$ at 40-50 days after mating for the ultrasonic Doppler method [48], 96.0-100\% for the ultrasonic echo method at 30-90 days after mating [23], and $100 \%$ for the ultrasonography at more than 22 days after mating $[15,16]$. Also, for endocrinological methods, the reported accuracies are: $90.3 \%$ at 26-30 days after mating for the urine estrogen measurement method [5], $88.0-96.4 \%$ at $16-24$ days after mating for the blood progesterone measurement method [9, 36, 38], and 93.7$98.0 \%$ at 24-32 days after mating for the blood estrone sulphate measurement method $[8,43,46]$. The accuracy of the present method of diagnosis based on the measurement of gestagen in feces by the Ovucheck bovine milk progesterone EIA kit was $96.0 \%$ at 21-25 days after mating, which is comparable to the accuracies of the above methods. It is also similar to the diagnostic accuracy of $96.3 \%$ at $17-$ 24 days after mating reported by the authors in a previous study using saliva as the measurement sample [29]. Moreover, as feces, used in the present study as the measurement sample, are much easier to collect than saliva, the present method is considered to have a higher clinical applicability.

In conclusion, this study has shown that the method of early pregnancy diagnosis in the sow based on the level of gestagen in the feces, measured by an Ovucheck bovine milk progesterone EIA kit, is simple in terms of sample collection, quick and accurate, and in addition, does not require any special equipment or skill. Therefore, this method of pregnancy diagnosis is considered to have high clinical applicability. 
ACKNOWLEDGMENTS. We express our gratitude to Dr. M. Furukawa of the Furukawa Pig Farm for providing the pigs, and to Dr. M. Kawaguchi of Denka Pharmaceutical Co., Ltd. for providing the Ovucheck bovine milk progesterone EIA kit.

\section{REFERENCES}

1. Balke, J. M. E. and Elmore, R. G. 1982. Pregnancy diagnosis in swine: A comparison of the technique of rectal palpation and ultrasound. Theriogenology 17: 231-236.

2. Bamberg, E., Mostl, E., Patzl, M., and King, G. J. 1991. Pregnancy diagnosis by enzyme immunoassay of estrogens in feces from nondomestic species. J. Zoo Wildl. Med. 22: 7377.

3. Cameron, R. D. A. 1977. Pregnancy diagnosis in the sow by rectal examination. Aust. Vet.J. 53: 432-435.

4. Choi, H. S., Kiesenhofer, E., Gantner, H., Hois, J., and Bamberg, E. 1987. Pregnancy diagnosis in sows by estimation of oestrogens in blood, urine or faeces. Anim. Reprod. Sci. 15: 209-216.

5. Cupps, P. T., Briggs, J. R., Hintz, H. F., and Heitman, H. Jr. 1966. Pregnancy diagnosis in the sow. J. Anim. Sci. 25: 646647.

6. Desaulniers, D. M., Goff, A. K., Betteridge, K. J., Rowell, J. E., and Flood, P. F. 1989. Reproductive hormone concentrations in faeces during the oestrous cycle and pregnancy in cattle (Bos taurus) and muskoxen (Ovibos moschatus). Can. J. Zool. 67: 1148-1154.

7. Diehl, J. R. and Day, B. N. 1970. Early diagnosis of pregnancy in swine by use of the vaginal biopsy technique. $J$. Anim. Sci. 31: 1032.

8. Edqvist, L. -E., Einarsson, S., and Larsson, K. 1980. Early pregnancy diagnosis in pigs by assay of oestrone sulphate in peripheral blood plasma. p. 27. In: Proc. Int. Pig Vet. Soc. 1980 Congr., Copenhagen, Denmark.

9. Ellendorff, F., Meyer, J. N., and Elsaesser, F. 1976. Prospects and problems of pregnancy and fertility diagnosis in the pig by aid of progesterone determination. Br. Vet. J. 132: 543550.

10. Fraser, A. F. and Robertson, J. G. 1967. The detection of foetal life on ewes and sows. Vet. Rec. 80: 528-529.

11. Gao, Y., Short, R. V., and Fletcher, T. P. 1988. Progesterone concentrations in plasma, saliva and milk of cows in different reproductive states. Br. Vet. J. 144: 262-268.

12. Günzler, O., Rattenberger, E., Görlach, A., Hahn, R., Hocke, P., Claus, R., and Karg, H. 1979. Milk progesterone determination as applied to the confirmation of oestrus, the detection of cycling and as an aid to veterinarian and biotechnical measures in cows. Br. Vet. J. 135: 541-549.

13. Hirata, S. and Mori, Y. 1995. Monitoring reproductive status by fecal progesterone analysis in ruminants. J. Vet. Med. Sci. 57: 845-850.

14. Hultén, F., Zhang, B. R., Forsberg, M., and Dalin, A. -M. 1995. Applying a progesterone assay to faecal samples collected from sows during the oestrous cycle. Reprod. Dom. Anim. 30: 101-105.

15. Inaba, T., Nakazima, Y., Matsui, N., and Imori, T. 1983. Early pregnancy diagnosis in sows by ultrasonic linear electronic scanning. Theriogenology 20: 97-101.

16. Irie, M., Ohmoto, K., and Kumagaya, S. 1984. Diagnosis of pregnancy in pigs by real time ultrasonic B-mode scan. Jpn.
J. Zootech. Sci. 55: 381-388 (in Japanese with English summary).

17. Johmen, M., Nakao, T., Kawata, K., and Tsunoda, N. 1980. Enzyme immunoassay of progesterone in swine serum. Jpn. J. Anim. Reprod. 26: 77-80 (in Japanese with English summary).

18. Kanchev, L. N., Marinove, CH. P., and Stankov, B. M. 1988. Bovine salivary progeterone: Application to the assessment of ovarian function and early pregnancy diagnosis. Anim. Reprod. Sci. 17: 1-8.

19. Keel-Diffey, S. J. 1963. Pregnancy diagnosis in swine. Vet. Rec. 75: 464.

20. Kirkpatrick, J. F., Shideler, S. E., Lasley, B. L., and Turner, J. W. 1991. Pregnancy determination in uncaptured feral horses by means of fecal steroid conjugates. Theriogenology 35 : 753-760.

21. Kirkpatrick, J. F., Shideler, S. E., and Turner, J. W. 1990. Pregnancy determination in uncaptured feral horses based on steroid metabolites in urine - soaked snow and free steroids in feces. Can. J. Zool. 68: 2576-2579.

22. Kubokawa, K., Ishii, S., Tajima, H., and Saitou, K. 1992. Analysis of sex steroids in feces of Giant Pandas. Zool. Sci. 9: 1017-1023.

23. Lindahl, I. L., Totsch, J. P., Martin, P. A., and Dziuk, P. J. 1975. Early diagnosis of pregnancy in sows by ultrasonic amplitude-depth analysis. J. Anim. Sci. 40: 220-222.

24. Lunaas, T. 1962. Urinary estrogen levels in the sow during estrous cycle and pregnancy. J. Reprod. Fertil. 4: 13-20.

25. Messier, F., Desaulniers, D. M., Goff, A. K., Nault, R., Patenaude, R., and Crete, M. 1990. Caribou pregnancy diagnoses from immunoreactive progestins and estrogens excreted in feces. J. Wildl. Manage. 54: 279-283.

26. Morino, S., Nakao, T., Tsunoda, N., and Kawata, K. 1984. A direct enzyme immunoassay of progeterone in skim milk of the cow. Jpn. J. Anim. Reprod. 30: 1-8 (in Japanese with English summary).

27. Moriyoshi, M., Tamaki, M., Nakao, T., and Kawata, K. 1996. Early pregnancy diagnosis in the sow by saliva progesterone measurement using a bovine milk progesterone qualitative test EIA kit. J. Vet. Med. Sci. 58: 737-741.

28. Moriyoshi, M., Tanaka, Y., Nakao, T., and Kawata, K. 1994. Early pregnancy diagnosis in the sow by saliva progesterone measurement using a bovine milk progesterone test EIA kit. J. Reprod. Dev. 40: j87-j92 (in Japanese with English summary).

29. Moriyoshi, M., Tanaka, Y., Nakao, T., and Kawata, K. 1996. A comparison of the accuracy of early pregnancy diagnoasis in the sow by saliva and plasma progesterone measurement using a bovine plasma progesterone test EIA kit. Anim. Sci. Technol. (Jpn.) 67: 679-685.

30. Morton, D. B. and Rankin, J. E. F. 1969. The histology of the vaginal epithelium of the sow in oestrus and its use in pregnancy diagnosis. Vet. Rec. 84: 658-662.

31. Mostl, E., Choi, H. S., Wurm, W., Ismail, N., and Bamberg, E. 1984. Pregnancy diagnosis in cows and heifers by determination of oestradiol-17 $\alpha$ in faeces. Br. Vet. J. 140: 287-291.

32. Nakao, T., Sugihashi, A., Sage, N., Tsunoda, N., and Kawata, K. 1983. An improved enzymeimmunoassay of progesterone applied to bovine milk. Br. Vet. J. 144: 262-268.

33. Oltner, R. and Edqvist, L. E. 1981. Progesterone in defatted milk: Its relation to insemination and pregnancy in normal cows as compared with cows on problem farms and individual problem animals. Br. Vet. J. 137: 78-87. 
34. Palme, R., Holzmann, A., and Mitterer, Th. 1994. Measuring fecal estrogens for the diagnosis of cryptorchidism in horses. Theriogenology 42: 1381-1387.

35. Riad-Fahmy, D., Read, G. F., Walker, R. F., Walker, S. M., and Griffiths, K. 1987. Determination of ovarian steroid hormone levels in saliva. An overview. J. Reprod. Med. 32: 254-272.

36. Robertson, H. A. and Sarda, I. R. 1971. A very early pregnancy test for mammals: its application to the cow, ewe and sow. J. Endocrinol. 49: 407-419.

37. Safar-Hermann, N., Ismail, M. N., Choi, H. S., Mostl, E., and Bamberg, E. 1987. Pregnancy diagnosis in zoo animals by estrogen detemination in feces. Zoo Biol. 6: 189-193.

38. Saga, N., Kawata, K., Nakao, T., and Tsunoda, N. 1985. Early pregnancy diagnosis in pigs by enzyme immunoassay of serum progesterone. Jpn. J. Anim. Reprod. 31: 68-73 (in Japanese with English summary).

39. Sanders, H., Rajamahendran, R., and Burton, B. 1994. The development of a simple fecal immunoreactive progestin assay to monitor reproductive function in swine. Can. Vet. J. 35: $355-358$.

40. Schwarzenberger, F., Möstl, E., Bamberg, E., and von Hegel, G. 1992. Monitoring of corpus luteum function by measuring progestergens in faeces of non-pregnant mares (Equus caballus) and Przewalski mares (Equus przewalskii). Anim. Reprod. Sci. 29: 263-273.

41. Schwarzenberger, F., Möstil, E., Palme, R., and Bamberg, E. 1996. Faecal steroid analysis for non-invasive monitoring of reproductive status in farm, wild and zoo animals. Anim. Reprod. Sci. 42: 515-526.

42. Sist, M. D., Youngblood, M. D., Williams, J. F., and Glade,
M. J. 1988. Salivary and serum estrone sulfate levels in pregnant mares. Equine Vet. Sci. 8: 164-167.

43. Sugiyama, S., Nakao, T., Tsunoda, N., and Kawata, K. 1985. An enzymeimmunoassay of serum oestrone sulphate and its application to early pregnancy diagnosis in pigs. $\mathrm{Br}$. Vet. J. 141: 60-68.

44. Taguchi, K., Shimizu, H., Iida, Y., Itoh, A., Moriyoshi, M., Nakao, T., Kawata, K., and Ishibashi, M. 1993. A plasma progesterone enzyme immunoassay kit used for pigs. J. Jpn. Vet. Med. Assoc. 46: 26-28 (in Japanese).

45. Takeuchi, K., Nakao, T., Moriyoshi, M., and Kawata, K. 1987. Clinical evalution of a progesterone enzyme immunoassay kit for cow's milk. J. Jpn. Vet. Med. Assoc. 40: 95-99 (in Japanese with English summary).

46. Tamamura, F., Kawata, K., Nakao, T., and Tsunoda, N. 1982. Enzyme immunoassay of serum estrone sulphate applied to swine early pregnancy diagnosis. J. Coll. Dairying 9: 337356.

47. Tanaka, S., Nakao, T., Kawahara, T., Moriyoshi, M., and Kawata, K. 1988. A plasma progesterone enzyme immunoassay kit used for heifers. J. Jpn. Vet. Med. Assoc. 41: 83-87 (in Japanese with English summary).

48. Too, K., Kawata, K., Fukui, Y., Sato, K., Kagota, K., and Kawabe, K. 1974. Pregnancy diagnosis in swine by an ultrasonic Doppler method and fatal heart rate changes with progress in pregnancy. J. Jpn. Vet. Med. Assoc. 27: 373-378 (in Japanese with English summary).

49. Wasser, S. K., Risler, L., and Steiner, R. A. 1988. Excreted steroids in primate faces over the menstrual cycle and pregnancy. Biol. Reprod. 39: 862-872. 